\title{
The "same bed, different dreams" of Vietnam and China: How (mis)trust could make or break it
}

\author{
Hong-Kong T. Nguyen \\ Quan-Hoang Vuong \\ Manh-Tung Ho \\ Thu-Trang Vuong
}

Copyright $\odot 2018$ Nguyen, Vuong, Ho, \& Vuong.

Working papers are in draft form. This working paper is distributed for purposes of comment and discussion only. It may not be reproduced without permission of the copyright holder. Copies of working papers are available from the author.

\section{TTU-ISR Working Paper 1802}

Version \#1: May 26, 2018

Thanh Tay University, Hanoi - Vietnam | Centre for Interdisciplinary Social Research 


\title{
The "same bed, different dreams" of Vietnam and China: how (mis)trust could make or break it
}

\author{
Hong-Kong T. Nguyen \\ Viet Panorama Media Monitoring, Hanoi, Vietnam \\ Quan-Hoang Vuong(*) \\ Thanh Tay University, Hanoi, Vietnam; and, \\ Université Libre de Bruxelles, Brussels 1050, Belgium \\ Manh-Tung Ho \\ Thanh Tay University, Hanoi, Vietnam \\ Ritsumeikan Asia Pacific University, Beppu City, Oita Prefecture, Japan \\ Thu-Trang Vuong \\ Sciences Po Paris, Campus de Dijon, Dijon 21000, France
}

(*) Corresponding author: qvuong@ulb.ac.be

\section{Abstract}

The relationship between Vietnam and China could be captured in the Chinese expression of "同 床异梦”, which means lying on the same bed but having different dreams. The two countries share certain cultural and political similarities but also diverge vastly in their national interests. This paper adds to the extant literature on this topic by analyzing the element of trust/mistrust in their interactions in trade-investment, tourism, and defense-security. The analysis shows how the relationship is increasingly interdependent but is equally fragile due to the lack of trust on both sides. The mistrust or even distrust of Chinese subjects run deep within the Vietnamese mindset, from the skepticism of Chinese investment, Chinese tourists, discrimination against ethnic Chinese, to the caution against Chinese aggression in the South China Sea. The paper forecasts that, despite the deep-seated differences and occasional mistrust, going forward, neither side would risk damaging the status quo even when tensions peak.

*JEL Classification: F50, F52, P21

*This manuscript version: May 27, 2018 (v.4) 


\section{Introduction}

The Chinese have this expression, 同床异梦, which means lying on the same bed but having different dreams. There is no equivalent expression in Vietnamese but the translation, đồng sàng dị mộng, is widely understood in Vietnam. The phrase somehow captures the dynamics between China and Vietnam - two countries lying in the same region with geographical and political proximity but ultimately having different goals or visions. This is understandable given that one is a larger power and the other smaller (Vuong, 2014; Vuong \& Tran, 2009). Vietnam has spent centuries to emancipate from Chinese domination but is still eclipsed by the northern giant. The question yet to be answered is whether Vietnam and China can find that equilibrium in their asymmetric relationship (Womack, 2000, 2003, 2006). Analyses on Vietnam-China relations are often centered around two approaches, one historical and the other geopolitical (Guan, 1998); (Napier \& Vuong, 2013).

There is no doubt that the thousand years, from 111 B.C. to A.D. 939, of Chinese rule have resulted in the Vietnamese assimilating certain aspects of Chinese culture while also acted as the cause for growing Vietnamese nationalism even today (Vuong \& Tran, 2009). Meanwhile, the geopolitical view would juxtapose Vietnam and China not only against themselves as close but unequal neighbors but also against an interplay of major political powers such as Russia (the former Soviet Union) and the U.S. Yet, it would be insufficient to look at the Vietnam-China dynamics via only the historical and geopolitical lenses; one should see each country as independent entities with certain similarities as well as wild differences.

This study, through an in-depth review of the Vietnam-China relations over the years via multiple factors of trade-economy and defense-security, postulates that trust or the lack thereof between the two countries would determine where they will be headed. The analysis seeks to show that the relationship is one that is more interdependent than ever but also has its fragile side as neither side fully trusts the other. Here, trust is defined as a belief that the other side is willing to reciprocate cooperation while mistrust is a belief that the other side would rather exploit one's cooperation (Kydd, 2007).

On the surface, even during their territorial conflicts in recent years, both countries have never explicitly expressed mistrust in each other; instead they have repeatedly affirmed their "comprehensive strategic partnership" is growing stably and sustainably. However, experts would likely notice that there is an undercurrent of wariness and even mistrust, especially on the side of Vietnam, attributable to the two's asymmetric position. On this note, the relationship from Vietnam's perspective could even be described by the phrase "trust but verify" that the U.S. President Ronald Reagan had once said in a meeting with Soviet Union Party Chief Mikhail Gorbachev (Kydd, 2007).

In terms of political ideologies, Vietnam can indeed trust that China would unreservedly back its socialist regime and ruling communist party; at the same time Vietnam still wants to verify that such backing means China is a true partner and not an expansionist ready to take over the Vietnam-claimed islands and waters (and the oil and gas underneath). From the Chinese side,

\footnotetext{
${ }^{1}$ The Russian proverbs is doveryai no prover yai.
} 
while having a small, close neighbor like Vietnam as a strategic partner is good for both trade and defense, it would nonetheless want to verify that Vietnam does not seek out intervention from the U.S. to resolve issues China sees as bilateral, not multilateral (case in point, the South China Sea disputes). These are just some examples of the myriads other matters that concern trust and mistrust between Vietnam and China.

Questions about objectivity are bound to be raised in a work on this subject written by a group of Vietnamese authors. When looking at the two-way interaction in trade, tourism, defense-security, the authors present facts and viewpoints from both sides in as far as it is possible.

Above all else, the authors admit that this work provides the Vietnamese perspective of the topic, including the threats and opportunities facing Vietnam in dealing with China in the new context, and therefore has its bias. The authors nonetheless hope to offer useful insights into the complexity of this relationship.

\section{Methods}

Two main methods are employed to collect and process information:

(i) Indirect: based on existing research and macro principles, both in Vietnamese and international sources, but strips away any lengthy and trivial discussion

(ii) Direct: based on actual fieldtrips and in-depth interviews

The 'trust' factor in the relationship will be examined through several contrasting layers:

- Economic power: As the world's biggest economy, China inevitably leads Vietnam in trade and economics. Yet, as Vietnam seeks to hold its own fort by reducing reliance on exports to China, it will have to develop spearheaded sectors and produce highquality products for export elsewhere.

- Military power: Any quantitative assessments of military might would put China leaps and bounds ahead of Vietnam. While this fact is also confirmed by the thousand years of Chinese domination over Vietnam, one cannot deny that, like a giant causing himself pain for kicking a road-blocking rock, China will find in Vietnam strong resistance and opposition for any expansionist attempts.

- International stance: If China sees itself as a hegemon, Vietnam, by contrast, has been building an image of a peace-loving nation.

- National strategies: China strives to be the number one world power while Vietnam is more content with ensuring its current socioeconomic stability as well as preserving and promoting pacificist and humanist values.

The literature review is expected to provide an overview of the relationship while the analysis will be based on three pillars: (i) geoeconomics and geopolitics, (ii) ideologies and culture, and (iii) mutual interests concerning trade and investment. The research sets out to identify any signs or elements critical to the understanding of and forecasting in Vietnam-China 
relations, taking into account actions from the external forces such as the ASEAN, Japan, the U.S., Russia, and the EU.

\section{Literature review}

Scholars worldwide have explored various common grounds between Vietnam and China, whether that be culture, history or institutional forms. In terms of sociodemographic, both countries are largely homogeneous with the majority of the population dominated by one ethnicity - the Han in China and the Kinh in Vietnam. In terms of cultural and historical experiences, both underwent periods of rural revolution and harsh post-revolutionary reforms. Perhaps the clearest example of persisting Chinese influence in Vietnam today is the predominant adherence to the religious philosophy of Confucianism, Taoism, and Buddhism. Many Vietnamese practices such as the burning of votive papers are widespread even though most people are unaware of its Chinese origin (Napier \& Vuong, 2013; Vuong et al., 2018).

The cultural influence aside, the two countries are most similar in their political system, both being one-party states ruled by their communist parties. Studies over the past decades have delved into various aspects when comparing and contrasting Vietnam and China, such as the development in education and science-technology (Elliott, 1982), the industrialization of the rural area (O'connor, 1998), the trade union movement (Zhu \& Fahey, 2000), the effects of globalization on cities (Leaf, 2002), the role of private enterprises (Heberer, 2003), or the use of medicines (Mao, Vu, Xie, Chen, \& Tang, 2015).

In addition, there were Woodside (2006), Painter (2008), Vu (2010) and Malesky \& London (2014) comparing the two's industrial policies, economic development and decentralization of the state; Bélanger \& Xi (2009), Michaud (2009), and Liu et al. (2012) looking into agricultural land, highland minority policies, and rural health insurance; Mol (2009) and Green et al. (2011) reviewing their health and environmental policies.

It is notable that the number of research into Sino-Vietnamese relations spiked dramatically after 2000. Google Scholar displays over 1 million results for the "Vietnam, China" keywords in the 2000-2018 period, versus just over 96,000 results for the years prior to 2000. Another noteworthy observation is the scholarly focus on Chinese influence on Vietnam's international relations during the war against the U.S. (Olsen, 2006; Rogers, 1976). This interest seems to have waned as research now look more to their economic cooperation or the territorial disputes. This begs the question of whether Beijing's power over Hanoi since the post-war era is predetermined enough to be unworthy of further research.

\section{Asymmetry in Vietnam-China relations}

When looking at Chinese and Vietnamese political ideologies, Womack (2000, 2003, 2006), Xiaosong \& Womack (2000) pointed out information asymmetry between the two as the structural cause of various misperceptions and misjudgments on both sides. Because Vietnam and China mostly differ in scale_-Vietnam's population is one-seventeenth that of China, and its territory is one-twenty-ninth as large, even when they adopt the same policies, different effects can arise (Womack, 2006). 
The asymmetry, unlikely to ever shift, is best summarized from each country's perception of the other, as follows:

(i) China sees Vietnam as a small country that is abrasive and untrustworthy. China's perceptions of and behaviors toward Vietnam are positioned within its strategic view of itself on the geopolitical world map. As such, what it prioritizes is not Vietnam's domestic changes but rather Vietnam's relations with other world players as well as how these relationships could affect China's position in the international arena.

(ii) Vietnam knows its vulnerability as a small neighbor lying to the southern border of China. Seeing China as a strong and aggressive country, Vietnam pays close attention to everything in Beijing, even the little things, to evaluate how these events could affect itself.

Womack (2006) argued that this asymmetric relationship is the cause of false forecasting by both Beijing and Hanoi of the other side's reactions. He suggested the secret to stability for both sides is to be able to neutralize and negotiate their disparities and to contain crises through diplomatic means. The key to reaching any consensus boils down to a matter of trust - can one side trust that the other will reciprocate its cooperation? To date, it appears that the leaderships of Beijing and Hanoi have been able to navigate through this diplomatic minefield peacefully.

An example illustrating this point is a Chinese vessel deliberately cutting Vietnamese ship cables in an escalating maritime territorial dispute in the South China Sea in 2011. After the first incident was reported on May 26, 2011 ${ }^{2}$, then Ministers of Defense of Vietnam Phung Quang Thanh and China Liang Guangjie held a meeting on the sidelines of the Shangri-La Dialogue in Singapore ${ }^{3}$. Both sides rated the incident as regrettable and pledged to not let it reoccur. Yet, four days later, on June 9, 2011, another Vietnamese ship reported its cables being cut by a Chinese vessel ${ }^{4}$. In early July 2011, unverified sources once again reported China disturbing Vietnam's exploration activities in the South China Sea ${ }^{5}$, which the latter called its East Sea.

The series of offenses, however, passed quietly as the media from both countries deliberately stayed silent on the $90^{\text {th }}$ anniversary of the establishment of the Communist Party of China (Thayer, 2011).

To grasp the full extent of the asymmetry, we will explore the trade and economic ties between the two countries as well as between the ten-member ASEAN bloc and China in the next sections.

\footnotetext{
${ }^{2}$ Tuoi Tre. https://tuoitre.vn/phan-doi-tau-trung-quoc-vi-pham-chu-quyen-lanh-hai-viet-nam-439870.htm [Published May 27, 2011; Accessed May 4, 2018]

${ }^{3}$ Tien Phong. https://www.tienphong.vn/xa-hoi/viet-nam-tiep-xuc-song-phuong-tai-doi-thoai-shangrila-540411.tpo [Published June 4, 2011; Accessed May 4, 2018]

${ }^{4}$ Tuoi Tre. https://tuoitre.vn/tau-trung-quoc-lai-pha-cap-tau-viet-nam-441681.htm [Published June 6, 2011; Accessed May 4, 2018]

${ }^{5}$ VnExpress. https://vnexpress.net/tin-tuc/the-gioi/trung-quoc-pha-cap-tau-tham-do-cua-viet-nam-2197200.html [Published June 6, 2011; Accessed May 4, 2018]
} 


\section{Trade and economy}

\section{Two-way trade}

The state of Vietnam-China economic cooperation fluctuated during different political periods, though border crossings or trading sites on land and at sea have consistently been more active than formal trading activities (T. M. H. Nguyen, 2015; Schoenberger \& Turner, 2008; Xiaosong \& Womack, 2000).

During the period from the $10^{\text {th }}$ century to 1885 - when the Treaty of Tianjin signed between France and China marked the permanent end of the vassal relationship between Vietnam and China, bilateral trade relations were marked as "firm but flexible," with China considered the main partner in both political and economic matters (T. M. H. Nguyen, 2015).

In the years before the two sides normalized relations in 1991, most trading activities were guided by the "Sino-Vietnamese Goods Exchange Agreement" that was signed in Beijing in July 1952 (Chen, 1969, p. 272). The agreement, renewed in 1954, allowed for the provision of more Chinese aid (military equipment) to North Vietnam as well as for the sending of injured Vietnamese soldiers to China for treatment (Chen, 1969). The two governments inked a number of economic-cultural cooperation pacts from 1967 to 1978, but most exchange activities were halted from 1979-1991 due to their border conflict (Cheng, 2011).

Since the normalization of bilateral relations in 1991, their two-way trade had reached \$93.69 billion in 2017, up from just \$32 million in 1991.

China has been Vietnam's largest trading partner since 2004, but Vietnam's annual trade deficit with China has been expanding rapidly since the country's admission to the World Trade Organization (WTO) in 2007 (Figure $1^{6}$ ). The trade gaps with China have persisted even as Vietnam managed to reduce its total trade deficit over the years, as shown in the red line of Figure 1.

Notably, Vietnam recorded trade surplus with China only in 2000 , at $\$ 135$ million or merely $5 \%$ of the total trade turnover. Since 2006, the proportion of Vietnamese trade deficit with China has hovered above $40 \%$ of the two-way trade. In the first quarter of 2018 , trade between Vietnam and China advanced $16.81 \%$ from a year earlier to $\$ 21.92$ billion, with the former maintaining a deficit of $\$ 5.42$ billion, according to the General Department of Vietnam Customs.

\footnotetext{
${ }^{6}$ Data from 2000-2008 were sourced from Vietnam's General Statistics Office (http://www.gso.gov.vn/default.aspx?tabid=629) while data from 2009-Q1/2018 were retrieved from the General Department of Vietnam Customs (https://www.customs.gov.vn).
} 


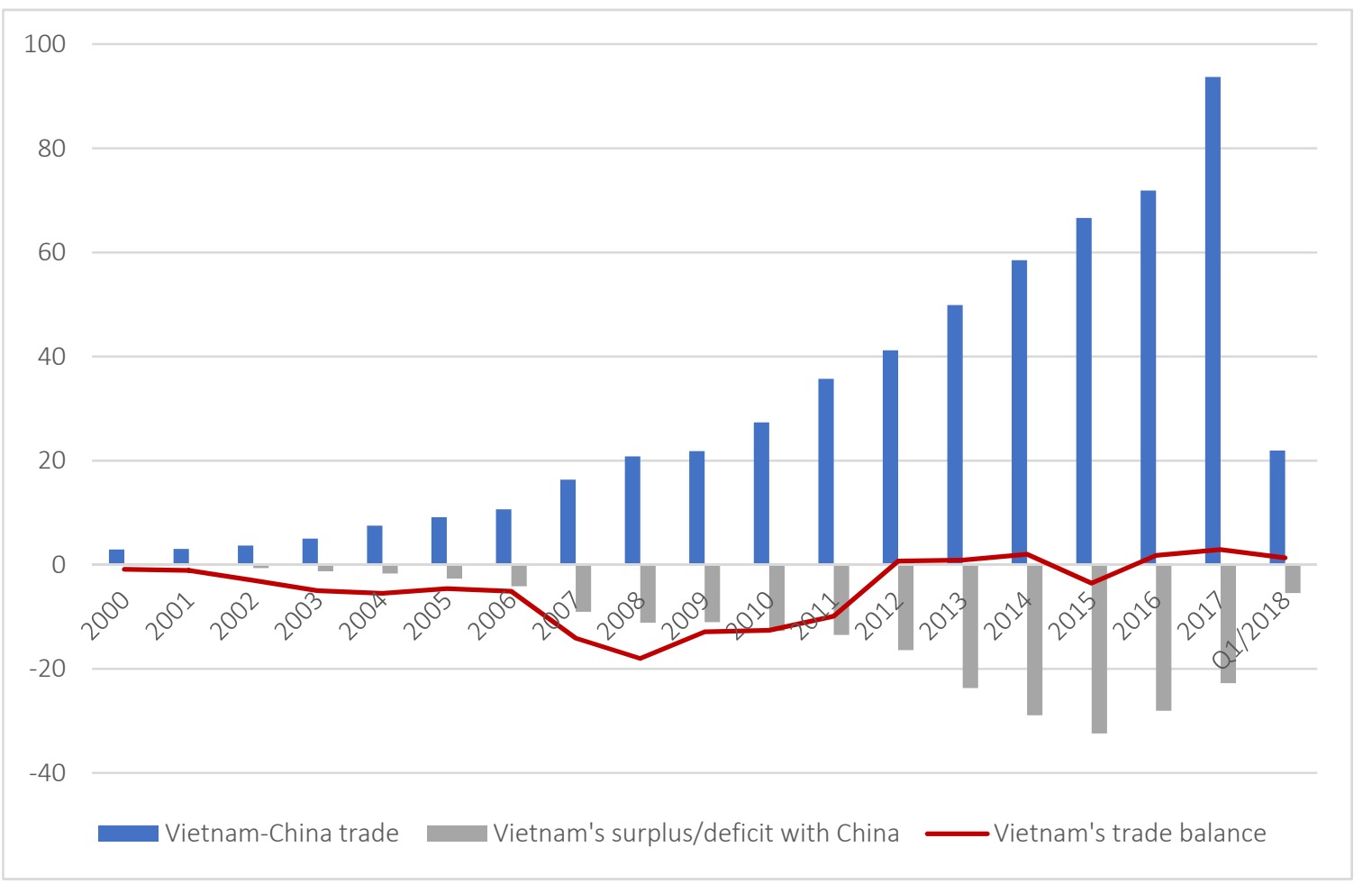

Figure 1: Vietnam-China bilateral trade turnover: 2000-Q1/2018 (unit: billion USD)

Going forward, Vietnam will likely continue to incur serious trade deficit with China because of the asymmetric level of technology and pricing. Vietnamese goods lack the competitive edge, both in price and quality, to Chinese goods, and thus, cannot yet penetrate this market. To explain the trade gap, Ngo (2017) listed three reasons:

(i) an imbalance in Vietnam's exports of low-value products and imports of higheradded-value products to/from $\mathrm{China}^{7}$,

(ii) consistent demand for Chinese goods in Vietnam due to the cheap price and wide variety of Chinese goods in comparison with those of goods from other countries, and,

(iii)the involvement of Chinese contractors in the majority of projects in heavy industrial sectors such as mining, thermal power plants and chemicals.

Vietnam's dependency on trade with China is magnified when the two countries' statistical methods yield wildly different numbers, such as the unaccounted for $\$ 20$ billion in Vietnam's imports in 2014, see Table $1^{8}$.

A study estimated that at least $50 \%$ of Vietnam's total imports could be unofficial purchases — such as smuggling — from China if such data are calculated (Ngo, 2017).

\footnotetext{
${ }^{7}$ Vietnam's main exports to China (70\% of total shipments) are raw minerals and farm produce, which are lowvalue and often suffer from fluctuating prices. Meanwhile, its imports from China ( $80 \%$ of total purchase) are chemicals, electronic and spare parts, and machinery.

${ }^{8}$ Source: https://comtrade.un.org/
} 


\begin{tabular}{|l|l|r|r|r|r|r|r|r|}
\hline & $\begin{array}{l}\text { Statistics } \\
\text { Office }\end{array}$ & $\mathbf{2 0 0 3}$ & $\mathbf{2 0 0 6}$ & $\mathbf{2 0 1 0}$ & $\mathbf{2 0 1 1}$ & $\mathbf{2 0 1 2}$ & $\mathbf{2 0 1 3}$ & $\mathbf{2 0 1 4}$ \\
\hline \multirow{2}{*}{$\begin{array}{l}\text { Vietnam } \\
\text { exports }\end{array}$} & Vietnam & 1.883 & 3.243 & 7.743 & 11.613 & 12.836 & 13.178 & 14.93 \\
\cline { 2 - 9 } & China & 1.457 & 2.486 & 6.984 & 11.117 & 16.229 & 16.892 & 19.9 \\
\cline { 2 - 9 } & Disparity & 0.426 & 0.757 & 0.759 & 0.496 & -3.393 & -3.714 & -4.97 \\
\hline \multirow{2}{*}{$\begin{array}{l}\text { impietnam } \\
\text { imports }\end{array}$} & Vietnam & 3.139 & 7.391 & 20.204 & 24.866 & 29.035 & 36.886 & 43.71 \\
\cline { 2 - 9 } & China & 3.183 & 7.463 & 23.102 & 29.092 & 34.213 & 48.586 & 63.736 \\
\cline { 2 - 9 } & Disparity & -0.044 & -0.072 & -2.898 & -4.226 & -5.178 & -11.7 & -20.026 \\
\hline
\end{tabular}

Table 1: Disparities in trade records between Vietnam and China (2003-2014); Unit: billion USD

The matter of mistrust looms large in the bilateral trade. Despite Vietnam's huge imports of Chinese goods and the fact that China is no longer a low-quality goods exporter (Vân, 2018), many Vietnamese consumers would still perceive either anything made-in-China to be of poor quality or China intentionally dumping substandard goods into this smaller market. The common sentiment among Vietnamese farmers and traders is that Chinese traders are often deceitful and opportunistic.

A popular claim from Vietnam is that Chinese traders would buy Vietnamese goods, particularly farm produce, in large volumes and at high prices at the beginning to stimulate farmers to produce massively; however, when the supply becomes superfluous, the traders would drive down the price or cancel their orders, causing huge losses for farmers. In 2013, Mr. Wei Zi Shen, Trade Consul of the Chinese Consulate General in Ho Chi Minh City, spoke to Vietnamese media to clear up such misperception, affirming that there is no such trick and all sales and purchases follow the market rules ${ }^{9}$. This statement, however, has not amounted to a more trusting relationship in trade between the two sides.

\section{China-ASEAN trade}

Trade between Vietnam and China should also be examined in relations to the trade between the Association of South-East Asian Nations (ASEAN) and China. This section provides an overview of this relationship.

\footnotetext{
${ }^{9}$ VietnamNet. http://english.vietnamnet.vn/fms/special-reports/74999/chinese-official-voices-over-complaints-ofchinese-traders-in-vietnam.html [Published April 30, 2013; Accessed on May 21, 2018]
} 
Since its founding in August 1967, the ASEAN has proved to be a fascinating case study of a diverse diplomatic community striving toward a sustainable collective consensus despite the occasional tensions and conflicts arising from within and without. The bloc, now comprising ten members ${ }^{10}$, has a combined population of over 630 million with an aggregate economic size surpassing USD2.5 trillion in 2016. Vietnam became a member of the ASEAN in 1995, possibly driven by pragmatic reasons of economic growth, political independence and regime survival in a post-Cold War era (V. T. Nguyen, 2007).

Besides the bilateral trade agreements its member countries have signed, the bloc as a whole has inked several trade agreements with other countries, including the ASEAN-China Free Trade Area (ACFTA) and the East Asia Free Trade Area (ASEAN+3). As of end-2016, China had been ASEAN's biggest trading partner for seven consecutive years, and the ASEAN had been China's third largest trading partner for five straight years (Wang, Xue, Zhu, \& Ge, 2017). However, it seems that Vietnam has not fully tapped the benefits these FTAs as during the 10 years since the ASEAN+3 took effect (2000-2010), China's exports to Vietnam surged by 25fold while Vietnam's exports to China rose by only five-fold.

The launch of the ASEAN Economic Community (AEC) on December 31, 2015 marked the realization of an ambitious strategy of regional economic integration. It paves the way for a single market more open for intra-regional movement of goods, services, investment, capital and people. Under the AEC framework, the more developed ASEAN members, namely, Singapore, Thailand, Indonesia, Brunei, Malaysia and the Philippines, had basically achieved zero tariffs as of the end of 2015, while the remaining four, namely Cambodia, Laos, Myanmar and Vietnam (ASEAN-CLMV), are given more leeway in cutting import duties until 2018 (Tsui, 2017).

Figure 2: China's trade with the ASEAN (2000-2017) (unit: billion USD) shows the upward trend in trade turnover between China and the ASEAN, with China's exports to the bloc consistently higher than its imports from the bloc since 2012. This means that the ASEAN will continue to see increasing trade deficit with China.

\footnotetext{
${ }^{10}$ Indonesia, Malaysia, the Philippines, Singapore, Thailand, Brunei Darussalam, Vietnam, Cambodia, Laos, and Myanmar
} 


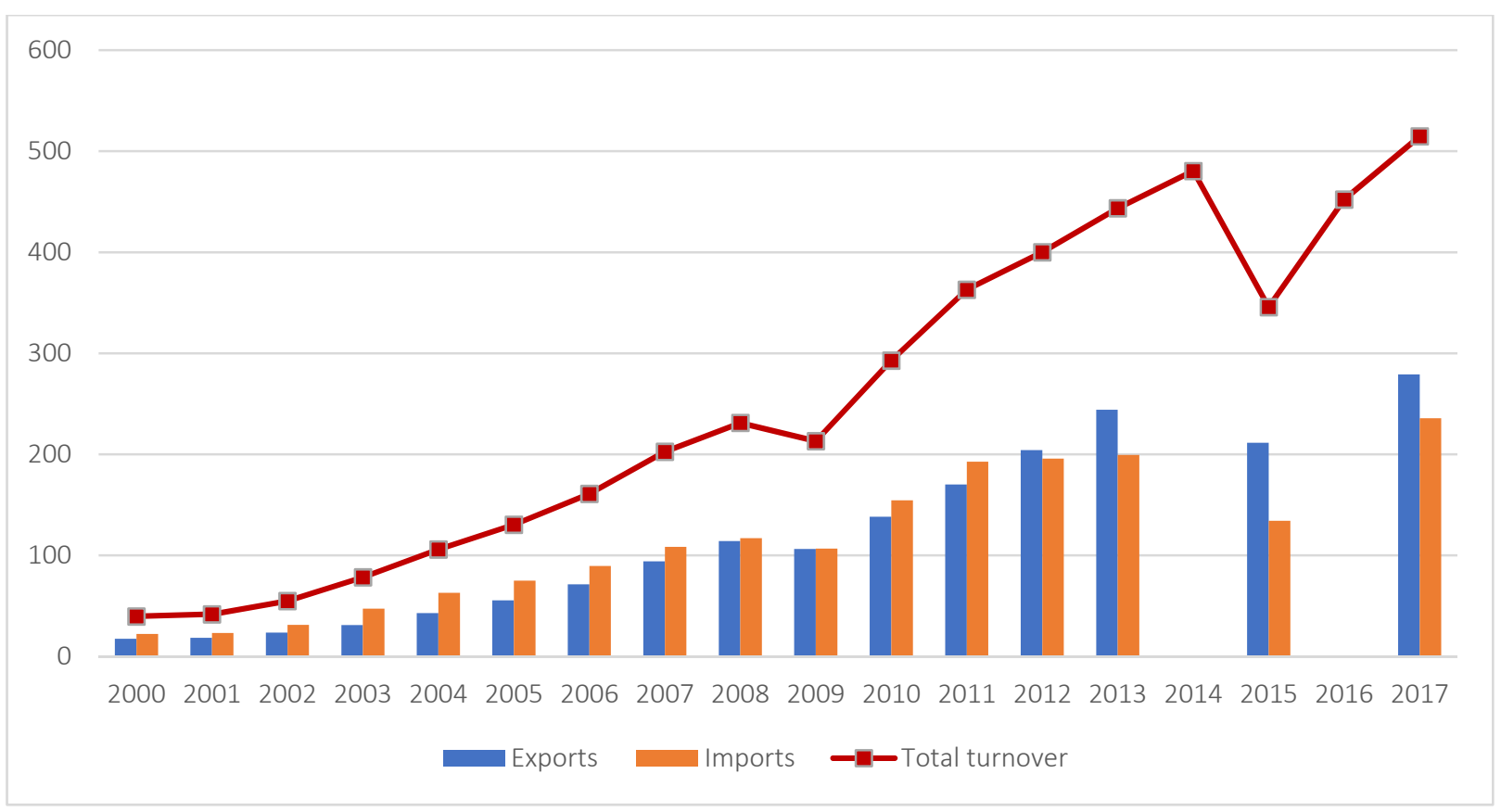

Figure 2: China's trade with the ASEAN (2000-2017) ${ }^{11}$ (unit: billion USD)

Table 2 shows that in 2014, China recorded trade surpluses worth a combined $\$ 81.05$ billion with six out of ten ASEAN countries, of which its surplus with Vietnam was the highest, $\$ 43.8$ billion or $54.04 \%$. Observers have pointed out how trade considerations will continue to shape the regional landscape as some ASEAN members rely more on trade with China than others (Stratfor, 2015). Experts have noted that Beijing could use the region's reliance on Chinese trade and investment to promote its political agendas, a reality that could hinder trustbuilding with the bloc, especially the two South China Sea claimant states of the Philippines and Vietnam (Stratfor, 2015).

\begin{tabular}{|c|c|c|c|}
\hline & $\begin{array}{l}\text { Trade balance } \\
\text { with China }\end{array}$ & $\begin{array}{l}\text { Share to total } \\
\text { trade turnover }\end{array}$ & $\begin{array}{l}\text { Two-way trade } \\
\text { turnover }\end{array}$ \\
\hline Cambodia & 2.798 & $74.41 \%$ & 3.76 \\
\hline Myanmar & -6.23 & $-24.95 \%$ & 24.97 \\
\hline Brunei & -0.19 & $-9.79 \%$ & 1.94 \\
\hline Vietnam & 43.8 & $51.20 \%$ & 85.54 \\
\hline
\end{tabular}

\footnotetext{
${ }^{11}$ Sources: (Jiang \& Li, 2013) and ASEAN-China Free Trade Area Business Portal (http://www.asean-cn.org)
} 


\begin{tabular}{lrrr}
\hline Singapore & 18.1 & $22.70 \%$ & 79.74 \\
\hline Laos & 0.07 & $1.93 \%$ & 3.62 \\
\hline Indonesia & 14 & $29.84 \%$ & 46.92 \\
\hline Philippines & 2.279 & $5.13 \%$ & 44.46 \\
\hline Thailand & -4 & $-5.51 \%$ & 72.62 \\
\hline Malaysia & -9 & $-8.82 \%$ & 102
\end{tabular}

Table 2: Trade balance between China and ASEAN countries in 2014 (unit: billion USD) 
Data in

Table 2 are visualized below, in Figure 3:

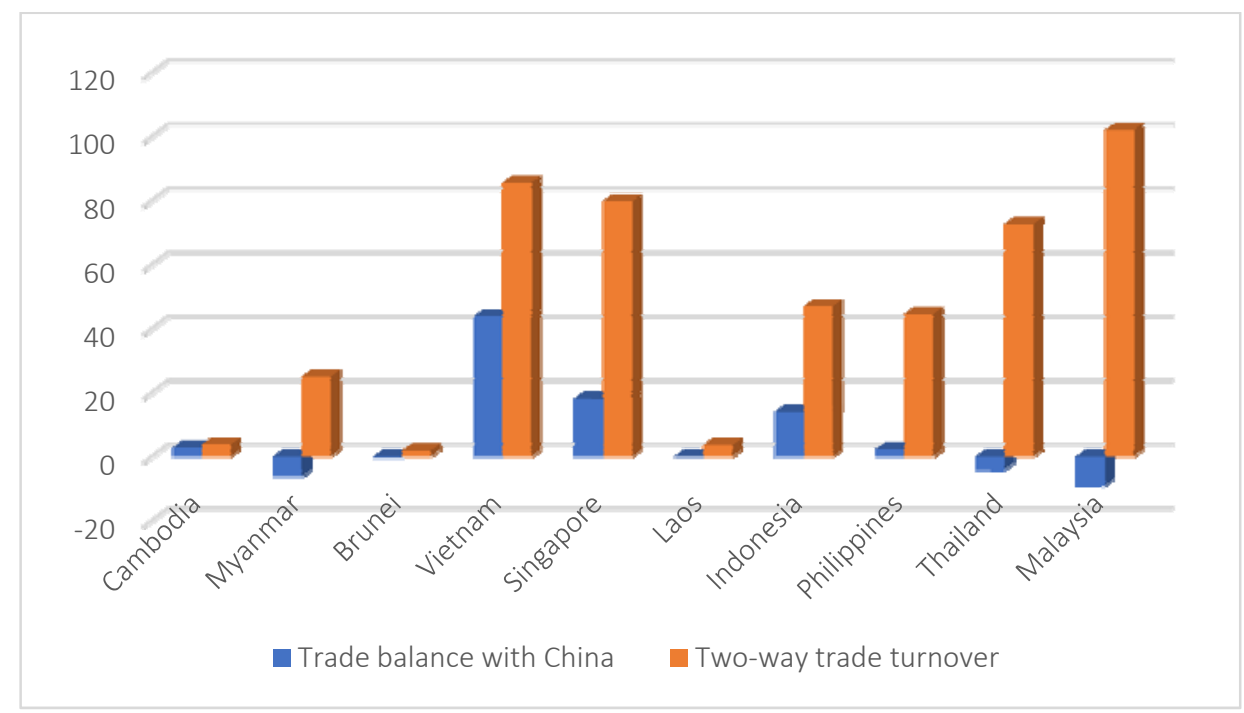

Figure 3: Trade balance between China and ASEAN countries in 2014 (Unit: billion USD)

\section{Foreign direct investment from China}

The majority of foreign direct investment (FDI) into Vietnam comes from Asian countries, with the top three countries being South Korea, Japan, and Singapore. This means FDI from China is low by comparison but nonetheless has been rising steadily in proportion to the total FDI inflow in Vietnam. Three phases can be observed here:

(i) 1991-2001: China had 110 projects with total registered capital of USD221 million as of end-2001. Most projects were small in scale (below USD1.5 million/project on average), often in joint venture form, and slow in implementation, thus, bear little impact on Vietnam's economic development.

(ii) 2002-2010: China's FDI picked up, with the more projects valued at over USD10 million and even USD100 million each.

(iii)2011-present: The recent years witnessed a dramatic increase in foreign Chinese investment in Vietnam as well as a shift of capital from small-scale fields to other areas.

Table 3 below presents the statistics on Chinese FDI into Vietnam in the 2005-2017 period. 


\begin{tabular}{|c|c|c|c|c|c|c|c|c|c|c|c|c|c|}
\hline Year & 2005 & 2006 & 2007 & 2008 & 2009 & 2010 & 2011 & 2012 & 2013 & 2014 & 2015 & 2016 & 2017 \\
\hline $\begin{array}{l}\text { FDI from } \\
\text { China (million } \\
\text { USD) }\end{array}$ & 229 & 254 & 397 & 522 & 728 & 987 & 1291 & 2368.6 & 2882.6 & 427.3 & 744.12 & 1875.2 & 2168.4 \\
\hline $\begin{array}{l}\text { FDI } \\
\text { China/Total } \\
\text { FDI }(\%)\end{array}$ & 0.74 & 0.76 & 0.99 & 1.05 & 1.27 & 1.51 & 1.77 & 3.33 & 3.67 & 2.1 & 3.08 & 7.69 & 6.04 \\
\hline
\end{tabular}

Table 3: FDI from China into Vietnam (2005-2017) 
There is a sentiment widely felt, and even acknowledged by a Chinese researcher (Zhang, 2012), across Vietnam that Chinese investors and traders look down on this market as one that is backward and low-technology. Contrary to the perception that Chinese investors are reluctant to transfer high technology to Vietnam, in one of the few studies that assessed the impacts of FDI between emerging markets, Kubny and Voss (2014) found that actual Chinese sourcing among Vietnamese firms is similar to that of other foreign investors due to the lack of competitive suppliers for advanced input materials. This means the sourcing of mostly low value-added products such as packaging materials and the import or sourcing from Vietnam-based foreign enterprises the more skill and technology-intensive products such as engine parts (Kubny \& Voss, 2014). Moreover, FDI from China into Vietnam has a statistically-significant positive effect on economic growth operating directly and through its interaction with labor, even if the effects diverge across economic sectors (T. B. Vu, Gangnes, \& Noy, 2008). It is also worth noting that, despite the geographic and cultural proximities, small- and medium Chinese firms in Vietnam have often found it hard to compete against Japanese and Korean multinational enterprises at the upper end and Vietnamese firms at the lower end of the market (Cooke \& Lin, 2012). Despite the aforementioned empirical evidence, Vietnam's mistrust of Chinese investment runs deep.

When this issue is put into the regional context, particularly the Southeast Asia, the Chinese government still stands out in its efforts to use foreign aid as a means to exert certain influence on these countries. China is seen as a key economic patron of Myanmar, Cambodia, and Laos and is also known for providing significant economic aid to Indonesia and the Philippines (Lum, Morrison, \& Vaughn, 2008). Meanwhile, besides the historical presence of the overseas Chinese businesses in Southeast Asia (Samphantharak, 2011), research have shown Chinese investors to also be in favor of pouring capital in countries that have similar culture, a high level of economic freedom but are politically risky or repressive, possibly because they can use the political experience in their home country to adapt to similar institutional environments (Y. Kang \& Jiang, 2012). Such criteria are fitting of many countries in Southeast Asia and, coupled with the ASEAN-China Free Trade Agreement, likely account for the growing Chinese FDI in the region since 2015 (Table $4^{12}$ ). As this trend will continue, experts forecast an increase in Chinese influence, both in economic and geopolitical terms, in the region $(\mathrm{Ng}, 2017)$.

\begin{tabular}{|l|r|c|r|r|r|r|r|r|}
\hline & \multicolumn{2}{|c|}{$\mathbf{2 0 1 3}$} & \multicolumn{2}{c|}{2014} & \multicolumn{2}{c|}{2015} & \multicolumn{2}{c|}{2016} \\
\hline & Value & \multicolumn{1}{|c|}{$\%$} & \multicolumn{1}{c|}{ Value } & $\%$ & Value & $\%$ & Value & $\%$ \\
\hline China & 6,426 & 5.1 & 6,990 & 5.4 & 8,256 & 6.8 & 9,211 & 9.5 \\
\hline Japan & 24,750 & 19.8 & 15,705 & 12.1 & 17,559 & 14.5 & 13,989 & 14.5 \\
\hline
\end{tabular}

${ }^{12}$ Source: ASEAN Secretariat, ASEAN FDI database 


\begin{tabular}{|l|r|r|r|r|r|r|r|r|}
\hline EU & 24,511 & 19.6 & 25,989 & 19.2 & 20,127 & 16.7 & 30,465 & 31.5 \\
\hline US & 7,157 & 5.7 & 14,748 & 11.3 & 13,646 & 11.3 & 11,657 & 12.1 \\
\hline
\end{tabular}

Table 4: FDI inflows into ASEAN from four biggest investors with share to total net inflows (2013-2016); Unit: million USD

In terms of investment trend, Chinese companies appear to be focused on infrastructural finance and other financial services in the region, in line with its government's Belt and Road Initiative involving ASEAN member states. To date, some major deals include the Bank of China's in Brunei Darussalam in 2016, the China Construction Bank's in Malaysia in 2017, and the Industrial and Commercial Bank of China's expansion to become the largest commercial bank in Laos in 2016.

Regarding the breakdown of Chinese FDI into the ASEAN by country, inflow into Singapore accounted for the majority, as shown in Table $5^{13}$ below. Please note that the figures for Vietnam are sourced from the ASEAN Secretariat database, and thus, are slightly different from the records by Vietnam's Ministry of Planning and Investment (Table 3).

\begin{tabular}{lrrrrrrr}
\hline & $\mathbf{2 0 1 0}$ & $\mathbf{2 0 1 1}$ & $\mathbf{2 0 1 2}$ & $\mathbf{2 0 1 3}$ & $\mathbf{2 0 1 4}$ & $\mathbf{2 0 1 5}$ & $\mathbf{2 0 1 6}$ \\
\hline $\begin{array}{l}\text { Brunei } \\
\text { Darussalam }\end{array}$ & 0.01 & 0 & 0 & 0 & 0 & 0 & 0 \\
\hline Cambodia & 126.94 & 179.68 & 367.76 & 286.75 & 553.89 & 537.68 & 501.54 \\
\hline Indonesia & 353.57 & 214.88 & 335.09 & 590.78 & $1,068.21$ & 323.54 & 354.72 \\
\hline Lao PDR & 45.57 & 278.32 & 0 & 0 & 614.26 & 665.09 & 709.98 \\
\hline Malaysia & -6.45 & -15.28 & 33.7 & 94.16 & 302.21 & 323.56 & $1,415.35$ \\
\hline Myanmar & $1,520.90$ & 670.6 & 482.2 & 792.6 & 70.54 & 52.44 & 205.48 \\
\hline Philippines & 0.19 & -4.11 & -1.61 & 6 & 46.61 & 59.02 & 19.55 \\
\hline Singapore & 699.3 & $5,462.50$ & $6,162.60$ & $2,696.20$ & $3,401.30$ & $3,812.70$ & $5,367.60$ \\
\hline Thailand & 633.43 & 20.92 & 598.46 & 938.86 & -81.77 & 305.47 & 255.61 \\
\hline Vietnam & 115.14 & 382.6 & 190.03 & 948.16 & 209.56 & 381.01 & 969.44
\end{tabular}

Table 5: FDI from China into ASEAN by country (2010-2016) (Unit: million USD)

\footnotetext{
${ }^{13}$ Source: ASEAN Secretariat - ASEAN FDI Database (https://data.aseanstats.org/fdi_by_country.php) as of 31 October 2017. Data for Brunei Darussalam were not available.
} 


\section{Foreign portfolio investment from China}

In addition to the direct investment channel, foreign portfolio investment (FPI) is an indirect way for Chinese investors to enter Vietnam. FPI has the advantages of faster capital liquidation, both outbound and inbound, and considerable influence on Vietnam's financial market. However, tracing the origin of FPI is difficult given that China-originated capital could have been invested in a third country such as Hong Kong, Singapore or some other tax haven.

\section{Tourism}

The trust issue emerges again when looking at the Chinese tourists to Vietnam. Below is some data on this industry. In 2017, Vietnam welcomed more than 12.92 million international visitors, up $29.1 \%$ on year, with Asia being its biggest tourism market. Official data also showed that China has consistently been Vietnam's top market - the number of Chinese visitors to Vietnam doubled to 4 million in 2013-2017 and the proportion of Chinese tourists over total foreign arrivals rose from $25 \%$ to $31 \%$ during those five years. Figure $4^{14}$ highlights again the importance of the Chinese market to Vietnam's tourism industry.

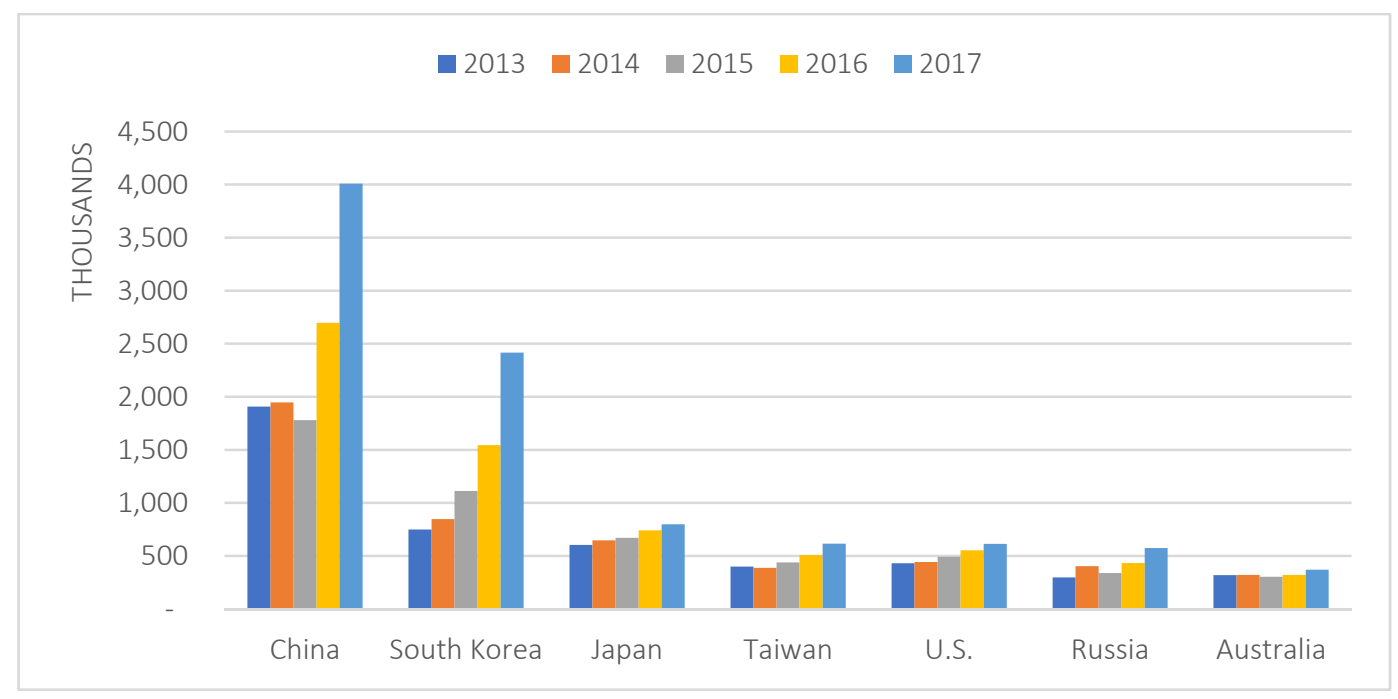

Figure 4: Tourists to Vietnam from top 7 markets (2013-2017) (unit: visitor)

What should be noted here is the influx of Chinese visitors to Vietnam during the years that the two countries' territorial disputes in the South China Sea keep on escalating. This is completely the opposite of what has happened to the Philippines, which is also tangled up in the South China Sea disputes with China. Particularly, Chinese tourist arrivals nearly halved from peak of over 40,000 during the Scarborough Shoal incident in April 2012 and later fell 40\% in 2014 after the Philippines filed its lawsuit to the United Nations on the

\footnotetext{
${ }^{14}$ Source: http://vietnamtourism.gov.vn
} 
South China Sea dispute (Credit Suisse, 2016). The case in Vietnam offers an example of the asymmetric ways people in Vietnam and China process the maritime disputes. On the one hand, continued Chinese aggression in the Vietnam-claimed waters and islands has pushed numerous Vietnamese nationalists on to the street for demonstrations. On the other hand, Chinese tourists, undeterred by the anti-Sino sentiment in the small neighbor, continue to flood well-known Vietnamese landmarks.

Various media reports have brought attention to the mushrooming of unlicensed tour guides in popular Vietnamese destinations that cater to the Chinese visitors by providing a China-centric perspective (Tatarski, 2017; Yan, 2017). These tour guides are known for spreading "incorrect information" on the territory and island disputes between the two countries ${ }^{151617}$. However, it is undeniable that Vietnam needs and welcomes the spending power of Chinese tourists, even if the average spending of Chinese tourists in Vietnam is lower than that of other foreign visitors (USD638/person vs. USD943/person ${ }^{18}$ ). Credit Suisse (2016) projected that a 30\% increase in Chinese tourism spending would boost Vietnam's gross domestic product (GDP) by nearly 1 percentage point. Vietnam's GDP grew $6.8 \%$ in 2017 - the fastest expansion since 2007.

\section{Defense and security}

\section{Defense expenditure}

This section gives a brief overview of the military expenditure in Vietnam and China. Comparing their expenditure may offer insights into their defense strategies. Table 6 shows a clear uptrend in military spending by the two countries in the 2010-2017 period.

\begin{tabular}{lcccccccc}
\hline & $\mathbf{2 0 1 0}$ & $\mathbf{2 0 1 1}$ & $\mathbf{2 0 1 2}$ & $\mathbf{2 0 1 3}$ & $\mathbf{2 0 1 4}$ & $\mathbf{2 0 1 5}$ & $\mathbf{2 0 1 6}$ & $\mathbf{2 0 1 7}$ \\
\hline China & 115,711 & 137,967 & 157,390 & 179,880 & 200,772 & 214,093 & 216,031 & 228,230 \\
\hline $\begin{array}{l}\text { Vietna } \\
\text { m }\end{array}$ & 2,672 & 2,686 & 3,360 & 3,727 & 4,255 & 4,562 & 5,017 & 5,073 \\
\hline
\end{tabular}

Table 6: Military expenditure by country, in millions of USD at current prices and exchange rates, 2010-2017 (SIPRI, 2017)

\footnotetext{
${ }^{15}$ Phap Luat Thanh Pho Ho Chi Minh. http://plo.vn/kinh-te/du-lich/truy-lung-huong-dan-vien-xuyen-tac-lichsu-viet-nam-757509.html. Published Mar 1, 2018 [Accessed May 6, 2018]

${ }^{16}$ Nguoi Lao Dong. https://nld.com.vn/thoi-su/nguoi-trung-quoc-huong-dan-du-lich-trai-phep-huong-dan-vientieng-hoa-keu-cuu-20170920155313893.htm Published Sep 20, 2017 [Accessed May 6, 2018]

${ }^{17}$ Tuoi Tre. https://tuoitre.vn/truc-xuat-ngay-huong-dan-vien-du-lich-trung-quoc-chui-1127398.htm Published Jun 30, 2016 [Accessed May 6, 2018]

${ }^{18}$ According to the Vietnam Tourism Advisory Board Secretariat. Source: VietnamNet. http://english.vietnamnet.vn/fms/travel/191881/foreign-tourists-spending-in-vietnam-remains-low.html Published Dec 11, 2017 [Accessed May 6, 2018]
} 
Looking at the comparison of military spending as a percentage of government spending (Figure 5) and GDP (Figure 6) during the same period confirms this observation.

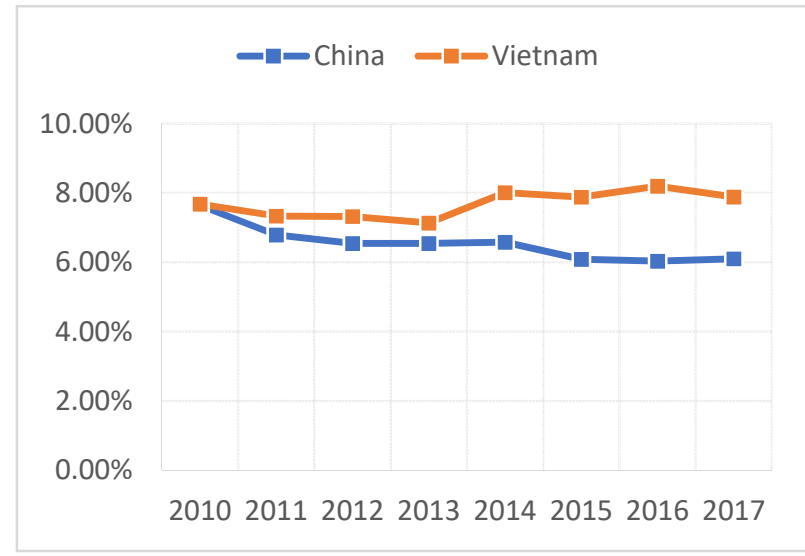

Figure 5: Military expenditure by country as percentage of government spending, 2010-2017

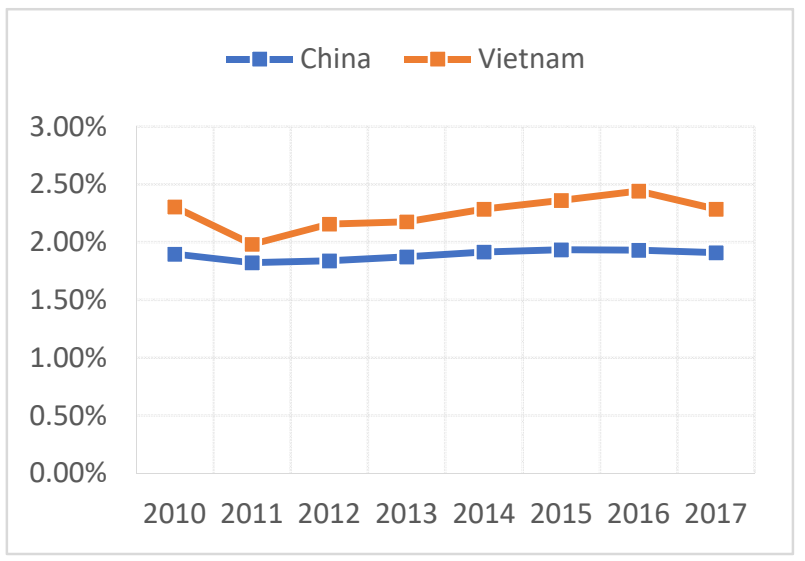

Figure 6: Military expenditure by country as percentage of GDP, 2010-2017

Source: (SIPRI, 2017)

\section{Implications}

If trade and economy offer the ground for Vietnam and China to grow closer, albeit with reservation, defense and security mark the more ambiguous realm in which the two sides clearly see the benefits of cooperation but have not been able to reach an agreement amicably. Over two decades have passed since the two countries normalized relations in 1991 — when the Cold War ended and the Soviet Union collapsed, four major issues, all related to shared land and sea borders, remain by and large unresolved despite frequent peaceful negotiations, namely the demarcations of the borders (i) on land and (ii) in the Gulf of Tonkin, and the sovereignty disputes over (iii) the Paracel Islands and (iv) the Spratly Islands. Kurlantzick (2015), in a report to the U.S. Council on Foreign Relations, suggested that the risk of a military confrontation involving Vietnam and China is growing, with three potential scenarios:

1. A limited, naval war could break out if tensions over their disputed territory continue to escalate in the South China Sea.

2. A land border exchanges of fire could happen, though not as bloody as the border war in 1979, if their border guards clash amid the already heightened maritime tensions.

3. Unwanted military incidents, e.g. planes buzzing each other or ships firing close to each other, could escalate as Beijing seeks to counter Hanoi's joint military exercises with its new strategic partners, which now include India, the Philippines, Singapore, the U.S., and Japan. 
The analysis indeed confirms that trust and mistrust could be matter of war and peace (Kydd, 2007). A clear example of this is the glitch in 2016 concerning the annual friendly border defense exchange, which Vietnam and China have agreed to alternately organize since 2013. In May 2016, General Fan Changlong, the Deputy Head of China's Central Military Commission, visited Vietnam and had meetings with senior Vietnamese officials, with initial media reports generally upbeat about future defense cooperation. However, the Chinese general abruptly ended his visit early, citing "reasons related to working arrangements" 19 and soon after the border defense exchange was also halted indefinitely. What had apparently happened was General Fan asking Vietnam to honor the commitments between their leaders and stop oil exploration in Vanguard Bank - which Vietnam claimed sovereignty over as part of its continental shelf but China disagreed. According to Thayer (2017), the Chinese general was angered after Prime Minister Nguyen Xuan Phuc claimed Vietnam had sovereign jurisdiction over this area, and thus, he cut short his visit and cancelled the military meeting. The Vanguard bank area of the South China Sea was also where a Chinese fishing vessel cut a Vietnamese boat's cable in May 2011; the incident triggered a series of weekend street protests in Hanoi at the time. However, far from the projection by Kurlantzick (2015), Vietnamese and Chinese leaders knew too well the importance of not letting tensions escalate to the point of no return, which implies a certain level of trust in each other even amid a serious dispute. The fourth Vietnam-China Border Defense Friendship Exchange was finally organized on September 23-24, 2017 in the Vietnamese northern province of Lai Chau and in the Chinese southern province of Yunnan. State media gave positive report of the results, saying it created "an atmosphere of friendship and solidarity." ${ }^{20}$ The resolution of the incident was similar to what had happened in 2014 when bilateral relations became tense after China deployed its Haiyangshiyou 981 (HYSY 981) oil rig to the waters claimed by Vietnam in the South China Sea. The two sides let the crisis recede before hosting the first border defense exchange that year.

A clear implication can be drawn from these events: neither side would be willing to risk damaging the status quo and upsetting the peace and stability in both countries and the region even when tensions peak. Leaders from both sides have consistently emerged from this kind of crisis reaffirming their "comprehensive strategic partnership" and ready to prepare for the next meeting or exchange. Preparations for the fifth border exchange ${ }^{21}$ are underway. The challenges for genuine defense-security cooperation between Vietnam and China, therefore, lie in their ability to trust each other to settle the territorial dispute amicably. Given the fundamental asymmetric relationship (Womack, 2006), false forecasting will likely ensue; only through trust-building can both sides be able to negotiate their disagreements and contain crises.

\footnotetext{
${ }^{19}$ New York Times. https://www.nytimes.com/2017/06/21/world/asia/china-vietnam-south-china-sea.html [Published June 21, 2017; Accessed May 24, 2018]

${ }^{20}$ People's Army. http://en.qdnd.vn/military/intl-relations-and-cooperation/4th-vietnam-china-border-defensefriendship-exchange-reviewed-486051 [Published October 24, 2017; Accessed May 24, 2018]

${ }^{21}$ People's Army. http://en.qdnd.vn/military/news/preparations-for-fifth-vietnam-china-border-defensefriendship-exchange-reviewed-490662 [Published March 9, 2018; Accessed May 24, 2018]
} 


\section{"Same bed"}

The negative perception among the Vietnamese of Chinese people does not mean a disregard for Chinese culture. By contrast, H. V. Nguyen (1993) notes in his exhaustive study of the ethnic Chinese population in Vietnam that after 1966, Chinese martial arts novels and movies completely dominated the Vietnamese market. Vietnamese media at the time would fail to attract readers if it did not publish Chinese martial arts or romance stories, while cinemas showing Western and Chinese movies also drew in a huge audience. People would be deemed "uncool" if they were ignorant of classical anecdotes or characters in the Chinese classics namely "The Three Kingdoms," "The Art of War," "Chronicles of the Eastern Zhou Kingdoms," "Water Margin," or "Strange Stories from a Chinese Studio," etc. (H. V. Nguyen, 1993). In the same way, the popularity of Chinese culture remains unchanged across Vietnam, even when political tensions sometimes escalated and spew over to this cultural domain. For example, in July 2016, after the Hague-based Permanent Court of Arbitration refused the legal basis claimed by China to islands in the South China Sea, many Chinese artists spoke up against the statement and shared a map with the U-shaped nine-dash line the delineates China's claim to nearly all of the resource-rich sea. In response, a local channel in southern Vietnam suspended the broadcast of a Chinese drama series after one of the lead actors voiced support for Beijing's controversial claims. The move and the strong anti-Sino sentiment, however, was short-lived and many channels continued to air Chinese shows afterward.

The fact that the leaderships from both countries have continued to affirm their "comprehensive strategic partnership" further highlights their desire to maintain the status quo. As Carlyle Thayer (2017) explained, within Vietnam's foreign policy terminology, China is at the top of the Vietnam's 16 strategic partnerships and is also the only country to be designated a comprehensive cooperative strategic partner. While this accolade is significant, it is also misleading given that the ruling Communist Party of Vietnam has adopted the "cooperation and struggle" struggle in regards to dealing with friendly countries where disagreements sometimes arise, such as with China (Thayer, 2016, 2017). The concepts go in line with the Vietnamese twin concepts of "partners of cooperation" (đối tác) and "objects of struggle" (đối tương), as stipulated in the CPV Central Committee's Resolution 8 dated in July 2003 (Thayer, 2017). Here, what can be seen is even without fully trusting the other side and mired in a serious maritime dispute, both Vietnam and China have managed to maintain cooperation and peace both bilaterally and regionally. One concept that could be accounted for the look of harmonious relationship between Vietnam and China, especially as reported by their state media, is their high regard for "face" (体面 or thể diện). Unlike in the West where the concept of face concerns mostly the individual, in Vietnamese and Chinese societies, because the Party's face is a collective image, face-losing or facegaining involves not just the individual party member but also the leaderships at large. This means, the two will likely "stay in the same bed" for the foreseeable future.

A close examination of the frequency of high-level exchanges between Vietnam and other countries from 2009 to 2016 reveals that China tops the list with 41 visits (both 
incoming and outgoing) (D. Kang \& Ma, 2017). What is most interesting in this study is the result that it is instead the U.S. that is chasing Vietnam, not the other way around as conventional wisdom would have. D. Kang \& Ma (2017) find that rather than allying with the U.S. to hedge against China, Vietnam has been engaged in regular bilateral exchanges and dialogues with China, with the number of incoming and outgoing visits between the two countries almost equal. This empirical evidence confirms the close bilateral partnership and signals clear efforts at trust-building.

In recent years, besides the usual bilateral cooperation in trade-investment or defensesecurity as detailed above, there are a number of issues that the two countries are aligned on. Vietnam is engaged in two major Beijing-led initiatives, namely the Asian Infrastructure Investment Bank (AIIB) and the "One Belt, One Road" (OBOR) that is also known as the Silk Road Economic Belt. In February 2017, during a meeting in Hanoi with senior officials of Vietnam's Ministry of Finance, AIIB Vice President and Chief Investment Officer D.J. Pandian had expressed the willingness to lend Vietnam up to \$100 million- $\$ 230$ million to implement infrastructure projects ${ }^{22}$. The offer came at a time when Vietnam is in need of low-interest loans. However, Vietnamese analysts suggested caution on two main grounds: (i) several large-scale projects in Vietnam with Chinese capital are sluggish and would often end up costing more than the initial capital; and (ii) the unstable Chinese yuan could result in Vietnam paying higher amounts for the loans than expected. The Vietnamese government nonetheless is interested in diversifying its lenders, which are now mainly the World Bank and the Asian Development Bank, and has called on AIIB to sponsor some local projects ${ }^{23}$. The issue of trust will no doubt resurface in Vietnam when there is increased investment from China.

Another similar trend seen in both countries recently is the intensifying crackdown against corrupt officials and Communist Party members, even very senior members. What is noteworthy is the fact that these efforts, despite its unprecedented moves and influence, are dismissed as political expediency or purge by outside observers (Lang, 2017). On this note, similar to what Lang (2017) observed in China, corruption in Vietnam is also framed within the West's ethical standards and economic interests to be a universal obstacle to economic growth and foreign investment. Being societies heavily influenced by Confucianism, the leaderships in both Vietnam and China instead thrive on the concept of "mandate of heaven" (天命 or thiên mẹnh) - under which power should only be bestowed onto the virtuous. As such, most analysts have undermined the ruling parties' own need to maintain ethical and political legitimacy as well as system stability through its genuine efforts to root out corrupt members. Perhaps this is one of the rare grounds that the two countries can share experience, both theoretical and practical, to improve trust-building. In fact, during a meeting on January 13, 2017 in Beijing, Vietnamese Party Chief Nguyen Phu Trong and Chinese Anti-corruption Chief Wang Qishan had agreed that building and readjusting the Party is an urgent, important

\footnotetext{
${ }^{22}$ VietnamNet. http://english.vietnamnet.vn/fms/business/172330/economists--vietnam-should-be-cautiousabout-loans-from-aiib.html [Published February 15, 2017; Accessed May 23, 2018]

${ }^{23}$ Xinhua. http://www.xinhuanet.com/english/2017-03/07/c 136110177.htm [Published March 7, 2017; Accessed May 23, 2018]
} 
and long-term mission that directly concerns the future of each Party and the socialist regime in Vietnam and China ${ }^{24}$.

\section{"Different dreams"}

\section{Two civilizations}

Scratch the veneer of diplomatic pleasantries and conventional understanding between Vietnam and China, one will find deep-seated differences. In the prologue of his book on the growing tensions in the South China Sea and their historical roots, Robert D. Kaplan (2014) brought up the Champa civilization that now lies in ruins in central Vietnam to drive home one point - this culture marked a fundamental difference between Vietnam and China both in cultural and aesthetic terms. This part of history occupies such a small part in the consciousness of Vietnamese people that most probably had forgotten that there used be the "Sinicized" Dai Viet kingdom in the north and its enemy the Khmer Empire and Champa in the south (Kaplan, 2014). Stressing that there had once lied two great civilizations in Vietnam, of India and China, Kaplan suggested a useful perspective for the South China Sea issue: one should not forget the presence of India in this region even as China becomes fiercely expansionist. His approach in a way also provides a refreshing lens for looking at the relationships and mutual influences between China and Vietnam. A direct and isolated view of either economics, culture, politics or ideologies will not suffice, instead we need to examine each issue through a multidimensional approach that draws on several elements simultaneously, whether that be culture, history, geography, geopolitics, economics, military, or ideologies.

\section{Different global agendas}

The "different dreams" of Vietnam and China are limited to their pursuits of different global agendas - the former multilaterization and sovereign integrity while the latter economic powerhouse and political hegemony. The asymmetric goals are the results of their asymmetric positions and perceptions (Womack, 2000, 2003, 2006). This imbalance is worsened in the face of piling information and the constantly changing global geo-economic and political powers. The majority of Vietnamese research institutions that live off state budget have yet to provide thoughtful up-to-date information monitoring and assessments on the China issue. The result is misguided and even erroneous studies on China within Vietnam, which consequently led to two extreme mistakes: (i) overwhelming fear and submission toward China's growing power, and (ii) misplacing Vietnam at the center of the international geopolitical map. Such imprudent views would give rise to a false sense of trust, inadequate attention to threats from the north, and lack of knowledge on Vietnam's actual capacity.

The biggest example of the diverging interests between the two countries is the sovereignty claims over different parts of the South China Sea. One of the ways this issue has been played out is China's behind-the-scene lobbying of Cambodia, an ASEAN member and

\footnotetext{
${ }^{24}$ VTV. http://vtv.vn/viet-nam-va-the-gioi/viet-nam-trung-quoc-chia-se-kinh-nghiem-chinh-don-dang-chongtham-nhung-20170113202458448.htm [Published January 13, 2017; Accessed May 23, 2018]
} 
its occasional ally, so that the bloc would fail to reach consensus on its joint statement concerning the territorial disputes (such as in 2012 and 2016). In 2017, after initial disagreement about whether to make subtle references to China's rapid expansion of its defense capabilities on artificial islands in disputed waters, ASEAN foreign ministers decided to issue a statement that called for non-militarization and noted concern about islandbuilding without explicitly naming China ${ }^{25}$. The deadlocks, in addition to the varying relationships ASEAN members have with other world powers, clearly indicate a lack of unity within this association (Ba, 2010). In most strategic decisions with major powers, ASEAN member states would have two considerations: (i) the bloc's common interest, and (ii) each member's national interests - with the latter taking precedence over the former. Here, one sees the matter of trust lies not just between Vietnam and China but also among ASEAN members. Dissatisfactions from both inside and outside the bloc are likely to persist and hinder ASEAN's ability to defend its current role (Ba, 2010). Against this context, Vietnam may not look to the ASEAN to back its claim in the South China Sea but instead should maintain good relations with major powers that have the capacity to challenge and deter China.

\section{Ethnic Chinese (Hoa) population in Vietnam}

Lastly, this study suggests a new way to understand the Vietnamese perspective, which is to glimpse into the colloquial expressions used in Vietnam to describe Chinese people and ethnic Chinese people. Here, the distrust is manifested in the Vietnamese's derogatory way of treating Chinese-related subjects.

The group of ethnic Chinese is known in the Vietnamese language as "Hoa people." According the 2009 census $^{26}$, there were about 800,000 Hoa people in Vietnam, the majority of whom are residing in the southern region - over 400,000 are in Ho Chi Minh City, formerly Saigon (西貢). Figure 7 shows that since the 1970s, after Vietnam was un the population of Hoa people as a percentage of total population has been falling.

\footnotetext{
${ }^{25}$ Reuters. https://www.reuters.com/article/us-asean-philippines-southchinasea-state-idUSKBN1AM0IR [Published August 6, 2017; Accessed May 24, 2018]

${ }^{26}$ Source: General Statistics Office - http://www.gso.gov.vn/default.aspx?tabid=512\&ItemID=10798
} 


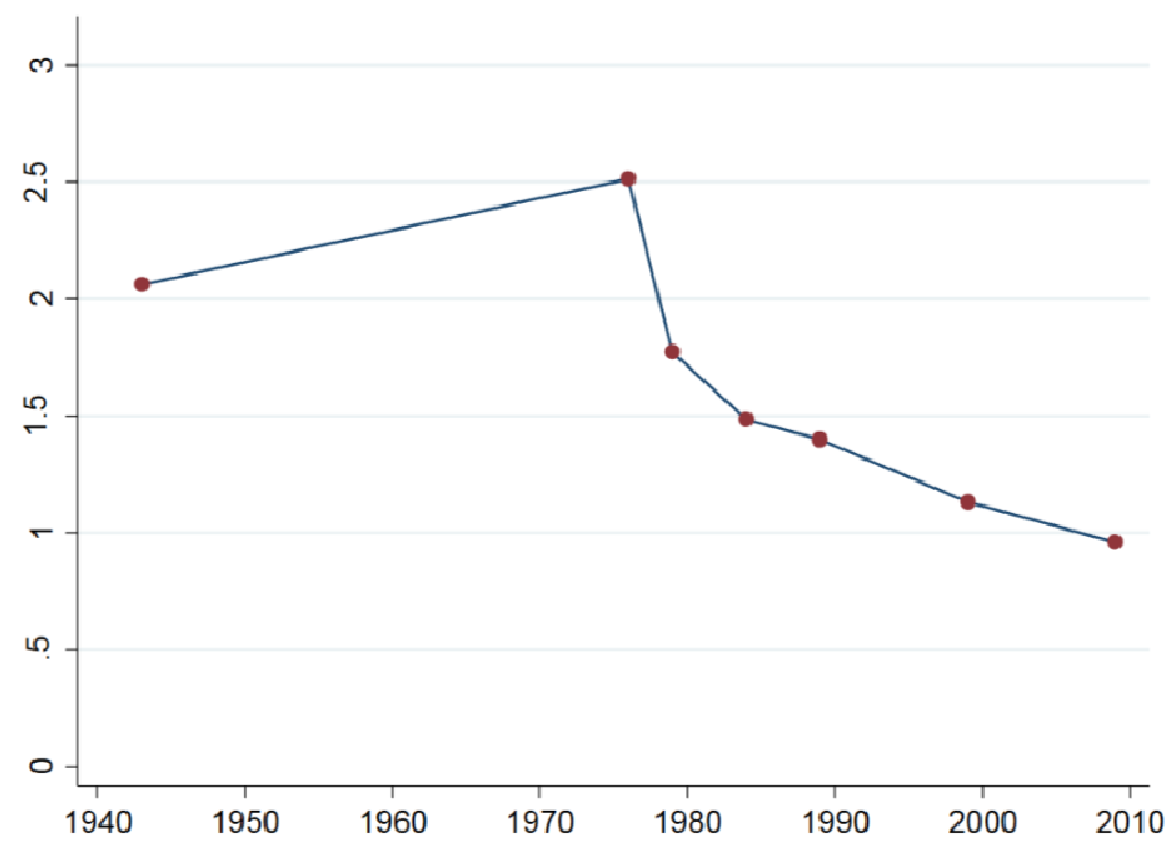

Figure 7: Ethnic Chinese population as a percentage of Vietnam's total population (19402010) (Nguyen-Viet \& Imai, 2017) ${ }^{27}$

Over the years, several studies have noted the disproportionately high involvement of the ethnic Chinese community in Vietnam's domestic business (Kim \& Kim, 2018; NguyenViet \& Imai, 2017; Tran, 1993; Tran \& Ta, 1997). Some notable companies are the stationary firm Thien Long, sugar refinery Thanh Thanh Cong, sandal and shoes maker Bitis, chemical cosmetics company My Hao, and plastic producer Duy Tan, among others. They are family businesses and generally supportive of each other within the formation of Chinatowns in southern Vietnam as well as within the wider networks of overseas Chinese communities (Kim \& Kim, 2018; H. V. Nguyen, 1993; Tran, 1993). A recent study even noted ethnic Chinese's positive economic impacts on Vietnam's regional economies, especially the private sector, and how the post-Vietnam War exodus of this demographics had likely left long-lasting negative economic impacts (Nguyen-Viet \& Imai, 2017).

The Vietnamese perception of the Hoa people, who are often lumped together as simply Chinese people even if they have Vietnamese nationality, is best understood through the local language. There are some pejorative terms used to call a Hoa person such as "cắc chú," "chú chẹt,", or "ba tàu”; or a mock melody ${ }^{28}$ implying this group only wants to profiteer in Vietnam (H. V. Nguyen, 1993). This lack of respect among the Vietnamese is reflected in today's colloquialism: a greedy person is called "tham nhu thằng Tàu" (greedy like a Chinese), speaking gibberish is called "nói Tiều nói Quảng” (saying Tieu and Quang

${ }^{27}$ Source: 1959, 1960 Statistical Yearbooks of South Vietnam; International Population Reports, Series P-95, No. 77, U.S. Department of Commerce; 1979, 1989, 1999, and 2009 Vietnam Population and Housing Census (Nguyen-Viet \& Imai, 2017).

${ }_{28}$ The Vietnamese version is "Ngộ là ngộ pênh Tàu, ngộ là ngộ mới xăng, mới xăng pênh Năm lầm dầu..." 
dialects $^{29}$ ), speaking in a roundabout, incoherent manner is called "vòng vo Tam Quốc"30 (beating around the bush), being inconsistent is deemed "đầu Ngô, minh Sö" (Ngo head, So body $^{31}$ ), etc. These expressions, which deserve a study of their own, support the claim that the Vietnamese people do not see the Chinese as trustworthy.

\section{Conclusion}

This paper has attempted to delve into the depth of Vietnam's relations with China as well as with the ASEAN and other major powers. It explores the asymmetry in the VietnamChina dynamics, showing how this is the structural cause of various misperceptions and misjudgments on both sides. In addition, through peeling off layers of trade-economy and defense-security cooperation between the two sides, the authors analyze how the matter of trust and mistrust - whether one side can find the other trustworthy enough to reciprocate cooperation - could make or break the status quo.

In terms of trade, China will continue to be Vietnam's biggest trading partner, as it has been since 2004. Vietnam will also likely incur deepening trade deficit with China because of the asymmetric level of technology and pricing, even though Vietnamese consumers are wary of Chinese goods and intentions. In terms of investment, despite empirical evidence showing that actual Chinese sourcing among Vietnamese firms is similar to that of other foreign investors, Vietnam continues to be skeptical of Chinese capital and its intentions. None of this will change after the launch of the ASEAN Economic Community (AEC) in end-2015 given that even the ASEAN records big trade deficit with China. The organization's reliance on Chinese trade and investment could give Beijing the leverage to push its political agendas, as some experts suggested. However, it is unclear whether trustbuilding with the two South China Sea claimant states (the Philippines and Vietnam) could be fruitful.

In terms of tourism, similar to the growing bilateral trade, the people-to-people exchanges also mark positive developments, with China consistently being the top tourism market of Vietnam in the past five years. Particularly, the number of Chinese visitors to Vietnam doubled to 4 million in 2013-2017 and the proportion of Chinese tourists over total foreign arrivals rose from $25 \%$ to $31 \%$ during the period. This paper notes the asymmetric ways people in Vietnam and China process the maritime disputes: the rise of Vietnamese nationalism against Chinese aggression versus the influx of undeterred Chinese tourists to popular Vietnamese sites. However, despite Vietnam's distrust of unlicensed tour guides serving Chinese visitors, the country still needs the money brought in by this group.

In terms of defense and security, SIPRI statistics show that military spending in both Vietnam and China has been rising steadily in 2010-2017, both in absolute number and as a

\footnotetext{
${ }^{29}$ Tieu is short for Trieu Chau (Chaozhou or 潮州) while Quang is short for Quang Dong (Guangdong or 广东). The two Chinese localities speak different dialects.

${ }^{30}$ The Vietnamese phrase refers to the meandering manner in talking that is comparable to the lengthy storytelling of the Chinese classic "The Three Kingdoms."

${ }^{31} \mathrm{Wu}$ was one of the states during the Western Zhou Dynasty and the Spring and Autumn period while Chu was a hegemonic, Zhou dynasty era state.
} 
percentage of GDP and government spending. Of the four major issues unresolved by the two countries, the sovereignty disputes over the Paracel Islands and the Spratly Islands in the South China Sea have been the most vexing, threatening diplomatic meetings and friendly border defense exchanges at times. Yet, based on past incidents, going forward, neither side would risk damaging the status quo even when tensions peak.

The paper shows how this relationship is more interdependent than ever but nonetheless remains fragile as neither side fully trusts the other. Despite being in the "same bed" in terms of cultural and political ideologies, the two are fundamentally different - with Vietnam's history rooted in the civilizations of both India and China, unlike the conventional wisdom of the sole heavy Chinese influence in Vietnam. The two countries are essentially chasing after different global agendas: one multilaterization and sovereign integrity while the latter economic powerhouse and political hegemony. Lastly, the lack of trust between the two could be understood through the Vietnamese's derogatory way of treating Chinese-related subjects, such as the ethnic Chinese people, whom are inherently deemed as untrustworthy or event deceitful.

There are no doubts other details of the relationship that this paper has failed to account for. A more exhaustive study should look at the highest level of party-to-party interaction to find hints of the direction both sides are heading. It appears that the diplomatic pleasantries do ring true to the extent that Hanoi and Beijing do want their relationship to be that harmonious. Yet, the underlying mistrust or distrust has in fact broken their rapport. One could expect to see in the Vietnam-China relations no major change for the time being, and certainly no crisis escalated so badly that would result into a military confrontation.

\section{References}

Ba, A. (2010). Regional Security in East Asia: ASEAN's Value Added and Limitations. Journal of Current Southeast Asian Affairs, 29(3), 115-130.

Bélanger, D., \& Li, X. U. (2009). Agricultural Land, Gender and Kinship in Rural China and Vietnam: A Comparison of Two Villages. Journal of Agrarian Change, 9(2), 204230.

Chen, K. C. (1969). Vietnam and China, 1938-1954. New Jersey: Princeton University Press.

Cheng, J. Y. S. (2011). Sino-Vietnamese Relations in the Early Twenty-first Century: Economics in Command? Asian Survey, 51(2), 379-405.

Cooke, F. L., \& Lin, Z. (2012). Chinese firms in Vietnam: Investment motives, institutional environment and human resource challenges. Asia Pacific Journal of Human Resources, 50(2), 205-226.

Elliott, D. W. (1982). Training Revolutionary Successors in Vietnam and China, 1958-1976: The Role of Education, Science, and Technology in Development. Studies in Comparative Communism, 15(1\&2), 34-70. 
Green, A., Gerein, N., Mirzoev, T., Bird, P., Pearson, S., Martineau, T., . . S Soors, W. (2011). Health policy processes in maternal health: a comparison of Vietnam, India and China. Health Policy, 100(2), 167-173.

Guan, A. C. (1998). Vietnam-China relations since the end of the cold war. Asian Survey, $38(12), 1122-1141$.

Heberer, T. (2003). Private entrepreneurs in China and Vietnam: Social and political functioning of strategic groups (Vol. 4): Brill.

Jiang, J., \& Li, C. (2013). Analysis of Trade Development between China and Association of Southeast Asian Nations. Journal of Behavioural Economics, Finance, Entrepreneurship, Accounting and Transport, 1(1), 15-20.

Kang, D., \& Ma, X. (2017). Who's Chasing Whom? Vietnam-US Relations and Theories of Alignment and Alliance. Paper presented at the The annual meeting of the ISA-Hong Kong, Hong Kong.

Kang, Y., \& Jiang, F. (2012). FDI location choice of Chinese multinationals in East and Southeast Asia: Traditional economic factors and institutional perspective. Journal of world business, 47(1), 45-53.

Kaplan, R. D. (2014). Asia's Cauldron: The South China Sea and the End of a Stable Pacific. New York, NY: Random House.

Kim, H., \& Kim, T. (2018). A Study of the Migration of Ethnic Chinese to Vietnam and the Establishment of Chinatowns. 인 문 논 총, 45, 85-99.

Kubny, J., \& Voss, H. (2014). Benefitting from Chinese FDI? An assessment of vertical linkages with Vietnamese manufacturing firms. International Business Review, 23(4). doi:10.1016/j.ibusrev.2013.11.002

Kurlantzick, J. (2015). A China-Vietnam military clash. Council on Foreign Relations, Center for Preventive Action, 85-86.

Kydd, A. H. (2007). Trust and mistrust in international relations. New Jersey: Princeton University Press.

Lang, B. (2017). China's anti-graft campaign and international anti-corruption norms: Towards a "new international anti-corruption order"? Crime, Law and Social Change, 1-17. doi:10.1007/s10611-017-9742-y

Leaf, M. (2002). A Tale of Two Village: Globalization and Peri-Urban Change in China and Vietnam. Cities, 19(1), 23-31.

Liu, X., Tang, S., Yu, B., Phuong, N. K., Yan, F., Thien, D. D., \& Tolhurst, R. (2012). Can rural health insurance improve equity in health care utilization? A comparison between China and Vietnam. International Journal for Equity in Health, 11(1), 10.

Lum, T., Morrison, W. M., \& Vaughn, B. (2008). China's "Soft Power" in Southeast Asia. Retrieved from

Malesky, E., \& London, J. (2014). The political economy of development in China and Vietnam. Annual Review of Political Science(17), 395-419. 
Mao, W., Vu, H., Xie, Z., Chen, W., \& Tang, S. (2015). Systematic review on irrational use of medicines in China and Vietnam. PloS one, 10(3), e0117710.

Michaud, J. (2009). Handling mountain minorities in China, Vietnam and Laos: from history to current concerns. Asian Ethnicity, 10(1), 25-49.

Mol, A. P. (2009). Environmental governance through information: China and Vietnam. Singapore Journal of Tropical Geography, 30(1), 114-129.

Napier, N. K., \& Vuong, Q. H. (2013). What We See, Why We Worry, Why We Hope: Vietnam Going Forward. Boise, ID: Boise State University CCI Press.

Ng, E. (2017). The Rise of Chinese FDI into ASEAN. Retrieved from https://en.nikkoam.com/articles/2017/10/the-rise-of-chinese-fdi-into-asean

Ngo, X. B. (2017). Main Characteristics of Vietnam-China Trade Relations, 2000-15. China Report, 53(3), 355-366. doi:10.1177/0009445517711510

Nguyen-Viet, T. A., \& Imai, M. (2017). The Effects of Ethnic Chinese Minority on Vietnam's Regional Economic Development in the Post-Vietnam War Period. The Journal of Development Studies, 1-18. doi:10.1080/00220388.2017.1393523

Nguyen, H. V. (1993). Ngưòi Hoa tại Việt Nam [Hoa people in Vietnam]. Paris: NBC.

Nguyen, T. M. H. (2015). Vietnam-China Trade Relations in the Feudal Period: From the Early 10th to the Late 19th Century. Journal of Mekong Societies (วารสาร สังคม ลุ่มน้ำ โขง), 11(3), 1-18.

Nguyen, V. T. (2007). Vietnam's Membership of ASEAN: A Constructivist Interpretation. Contemporary Southeast Asia, 29(3).

O'connor, D. (1998). Rural Industrial Development in Vietnam and China: A Study in Contrasts. MOST: Economic Policy in Transitional Economies, 8(4), 7-43.

Olsen, M. (2006). Soviet-Vietnam Relations and the Role of China, 1949-64: Changing Alliances. London: Routledge.

Painter, M. (2008). From Command Economy to Hollow State? Decentralization in Vietnam and China. Australian Journal of Public Administration, 67(1), 79-88.

Rogers, F. (1976). Sino-American Relations and the Vietnam War, 1964-66. China Quarterly(66), 293-314.

Samphantharak, K. (2011). The Rise of China and Foreign Direct Investment from Southeast Asia. Journal of Current Southeast Asian Affairs, 30(2), 65-75.

Schoenberger, L., \& Turner, S. (2008). Negotiating Remote Borderland Access: Small Scale Trade on the Vietnam-China Border. Development and Change, 39(4), 667-696.

SIPRI. (2017). SIPRI Military Expenditure Database. Retrieved May 24, 2018, from Stockholm International Peace Research Institute https://www.sipri.org/databases/milex

Stratfor. (2015). How China Uses Trade to Influence the South China Sea. Retrieved from https://worldview.stratfor.com/article/how-china-uses-trade-influence-south-china-sea 
Suisse, C. (2016). ASEAN's pivot to China-shifting to a fast track. Retrieved from https://research-doc.credit$\underline{\text { suisse.com/docView?language }=E N G \& \text { format }=P D F \& \text { sourceid }=\text { emcmt\&document id }}$ $=1067047631 \&$ serialid $=$ L90xGwS\%2bwO3ZH1SHCxlp18NOqRybz5p2xCPrU5YKI $7 \mathrm{U} \% 3 \mathrm{~d}$

Tatarski, M. (2017). The Good, the Bad and the Ugly of Chinese Tourists in Vietnam. Retrieved from http://www.scmp.com/week-asia/society/article/2058279/good-badand-ugly-chinese-tourists-vietnam

Thayer, C. (2011). Chinese Assertiveness in the South China Sea and Southeast Asian Responses. Journal of Current Southeast Asian Affairs, 30(2), 77-104.

Thayer, C. (2016). Vietnam's Strategy of 'Cooperating and Struggling' with China over Maritime Disputes in the South China Sea. Journal of Asian Security and International Affairs, 3(2), 200-220.

Thayer, C. (2017). Vietnam: China a Partner of Cooperation and Object of Struggle. Retrieved from https://cpianalysis.org/2017/09/11/vietnam-china-a-partner-ofcooperation-and-object-of-struggle/

Tran, K. (1993). The Ethnic Chinese and Economic Development in Vietnam. Singapore: Institute of Southeast Asian.

Tran, K., \& Ta, H. P. (1997). Ethnic Chinese in Vietnam and their identity. Ethnic Chinese as Southeast Asians (pp. 267-295). New York: Palgrave Macmillan.

Tsui, W. (2017). ASEAN: Market Profile. Retrieved from http://emerging-marketsresearch.hktdc.com/business-news/article/Asia/ASEAN-MarketProfile/mp/en/1/1X000000/1X09WKZD.htm

Vân, H. (2018). Trung Quốc không còn là thị trường chất lượng thấp [China is no longer a low-quality market]. Retrieved from http://nhipcaudautu.vn/thuong-truong/trungquoc-khong-con-la-thi-truong-chat-luong-thap-3323772/

Vu, T. (2010). Paths to Development in Asia: South Korea, China, Vietnam, and Indonesia: Cambridge University Press.

Vu, T. B., Gangnes, B., \& Noy, I. (2008). Is foreign direct investment good for growth? Evidence from sectoral analysis of China and Vietnam. Journal of the Asia Pacific Economy, 13(4), 542-562.

Vuong, Q. H. (2014). Vietnam's Political Economy: A Discussion on the 1986-2016 Period (May 21, 2014). CEB-ULB Working Paper N¹4/010. Available at SSRN: https://ssrn.com/abstract=2439809 or http://dx.doi.org/10.2139/ssrn.2439809.

Vuong, Q. H., Ho, M. T., La, V.-P., Dam, V. N., Bui, Q. K., Nghiem, P. K. C., . . Napier, N. K. (2018). "Cultural additivity" and how the values and norms of Confucianism, Buddhism, and Taoism co-exist, interact, and influence Vietnamese society: A Bayesian analysis of long-standing folktales, using R and Stan. Working Paper CEB No. 18-015, Université Libre de Bruxelles (March 4). 
Vuong, Q. H., \& Tran, T. D. (2009). The Cultural Dimensions of the Vietnamese Private Entrepreneurship. IUP Journal of Entrepreneurship Development, 6(3/4), 54-78.

Wang, S., Xue, X., Zhu, A., \& Ge, Y. (2017). The Key Driving Forces for Geo-Economic Relationships between China and ASEAN Countries. Sustainability, 9(12), 2363.

Womack, B. (2000). International Relationships at the Border of China and Vietnam: An Introduction. Asian Survey, 40(6), 981-986.

Womack, B. (2003). Asymmetry and systemic misperception: China, Vietnam and Cambodia during the 1970s. Journal of Strategic Studies, 26(2), 92-119.

Womack, B. (2006). China and Vietnam: The Politics of Asymmetry. New York: Cambridge University Press.

Woodside, A. (2006). Lost Modernities: China, Vietnam, Korea and the Hazards of World History. Cambridge, Massachusetts: Harvard University Press.

Xiaosong, G., \& Womack, B. (2000). Border Cooperation between China and Vietnam in the 1990s. Asian Survey, 40(6), 1042-1058.

Yan, A. (2017). Big rise in the number of Chinese tourists to Vietnam. Retrieved from http://www.scmp.com/news/china/society/article/2097575/big-rise-number-chinesetourists-vietnam

Zhang, N. (2012). Research on Trading Relations between China and Vietnam. Journal of Engineering, 1(2), 30-35.

Zhu, Y., \& Fahey, S. (2000). The challenges and opportunities for the trade union movement in the transition era: two socialist market economies - China and Vietnam. Asia Pacific Business Review, 6(3-4), 282-299. 